\title{
Primary ciliary dyskinesia. From symptoms to diagnosis. A case report of a 4.5 -year-old girl
}

\author{
Pierwotna dyskineza rzęsek. Od objawu do rozpoznania. Opis przypadku 4,5-letniej dziewczynki
}

\author{
1 Department of Allergology and Pulmonology, Institute of Tuberculosis and Lung Diseases, Jan and Irena Rudnik Field Division, Rabka-Zdró, Poland \\ ${ }^{2}$ Department of Pulmonology, Institute of Tuberculosis and Lung Diseases, Jan and Irena Rudnik Field Division, Rabka-Zdrój, Poland \\ Correspondence: Department of Allergology and Pulmonology, Institute of Tuberculosis and Lung Diseases, Jan and Irena Rudnik Field Division, prof. Jana Rudnika 3B, 34-700 Rabka-Zdrój, Poland
}

Abstract Primary ciliary dyskinesia is a rare genetic disease. Early diagnosis is aimed at delaying pulmonary complications, such as bronchiectasis, reducing lung dysfunction and hearing impairment, as well as providing optimal treatment of rhinitis and sinusitis. The awareness of the disease is still poor, and primary ciliary dyskinesia is often underdiagnosed or confused with other diseases, such as asthma. Chronic productive cough and rhinitis, which are the main symptoms, develop already in infancy. Therefore, differential diagnosis is a key element of the diagnostic and therapeutic process. The area of search depends on patient's age, the nature of symptoms (type of cough, time of symptom onset, repeatability of symptoms), concomitant symptoms and family history. We present a case report of a 4.5-year-old girl with recurrent lower respiratory tract infections and chronic cough, monitored for asthma and unsuccessfully treated with antiasthmatics.

Keywords: primary ciliary dyskinesia (PCD), diagnosis, chronic cough

Streszczenie Pierwotna dyskineza rzęsek należy do chorób rzadkich o podłożu genetycznym. Wczesne ustalenie rozpoznania ma na celu opóźnienie wystąpienia powikłań płucnych - rozstrzeni oskrzeli, zmniejszenie utraty funkcji płuc i upośledzenia słuchu, oraz optymalne leczenie zapalenia błony śluzowej nosa i zatok. Świadomość choroby jest ciągle zbyt niska i pierwotna dyskineza rzęsek często bywa nierozpoznawana lub mylona z innymi schorzeniami, np. z astmą oskrzelową. Przewlekły produktywny kaszel i nieżyt nosa - główne objawy choroby - pojawiają się już w wieku niemowlęcym. Dlatego też bardzo istotnym elementem procesu diagnostyczno-terapeutycznego jest diagnostyka różnicowa. Obszar poszukiwań determinują wiek pacjenta, rodzaj dolegliwości (charakter kaszlu, czas wystąpienia dolegliwości, powtarzalność objawów), objawy towarzyszące, wywiad rodzinny. W niniejszej pracy przedstawiono przypadek 4,5-letniej dziewczynki z nawrotowymi infekcjami dolnych dróg oddechowych, przewlekłym kaszlem, obserwowanej w kierunku astmy oskrzelowej, u której leczenie przeciwastmatyczne okazało się nieskuteczne.

Słowa kluczowe: pierwotna dyskineza rzęsek (PCD), diagnostyka, przewlekły kaszel 


\section{INTRODUCTION}

$\longrightarrow$ hronic cough and recurrent respiratory infections are currently among the most common reasons of visits to pulmonologists and allergologists. These symptoms may be caused by infectious agents, congenital defects of the airways or psychogenic factors (Tab. 1) ${ }^{(1)}$. In addition to mild conditions, which often resolve spontaneously, chronic disorders frequently leading to irreversible respiratory lesions, respiratory failure and severe complications may also occur. Therefore, differential diagnosis is a key element of the diagnostic and therapeutic process. The area of search depends on patient's age, the nature of symptoms (type of cough, time of symptom onset, repeatability of symptoms), concomitant symptoms and family history. We present a case report of a child with recurrent lower respiratory tract infections and chronic cough, monitored for asthma and unsuccessfully treated with antiasthmatics.

\section{CASE REPORT}

A nearly 4.5-year-old girl was referred to the Department of Pulmonology, Institute of Tuberculosis and Lung Diseases in Rabka-Zdrój for extended pulmonological diagnosis.

The child was born at 41 weeks from first pregnancy via vaginal delivery, with a birth weight of $3,340 \mathrm{~g}$ and an Apgar score of 7/10/10/10 at 1/3/5/10 minutes, respectively. On the second day of life, the girl was reluctant to eat and developed cough. Physical examination revealed snuffles, nasal discharge as well as dry rales over the lung fields on auscultation. Lung radiography and laboratory testing were unremarkable. A clinical diagnosis of pneumonia was established. Broad-spectrum antibiotic therapy, parenteral nutrition, and physical therapy were included, leading to improved general condition. Screening tests, including immunoreactive trypsinogen test, were performed. An ENT (ear, nose, throat) check was ordered due to abnormal hearing screening.

The girl was re-admitted at 6 weeks of age due to pneumonia. The child was put under the care of a pulmonologist. Sweat test was normal. Further re-admissions due

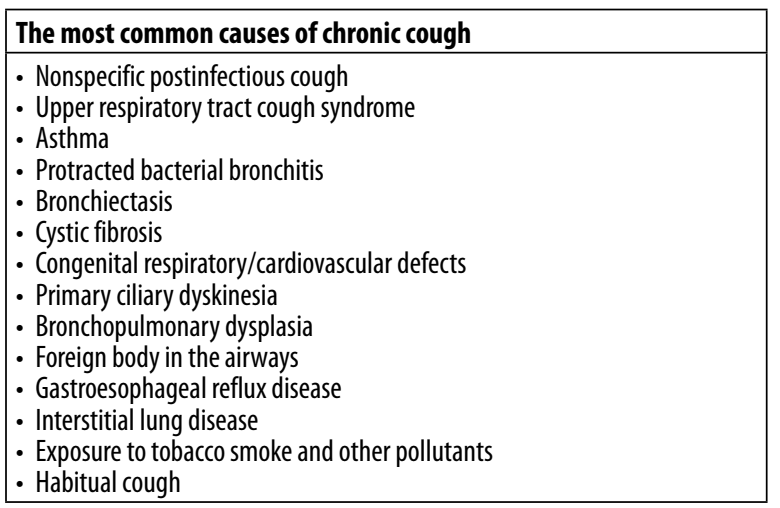

Tab. 1. The most common causes of chronic cough ${ }^{(1)}$

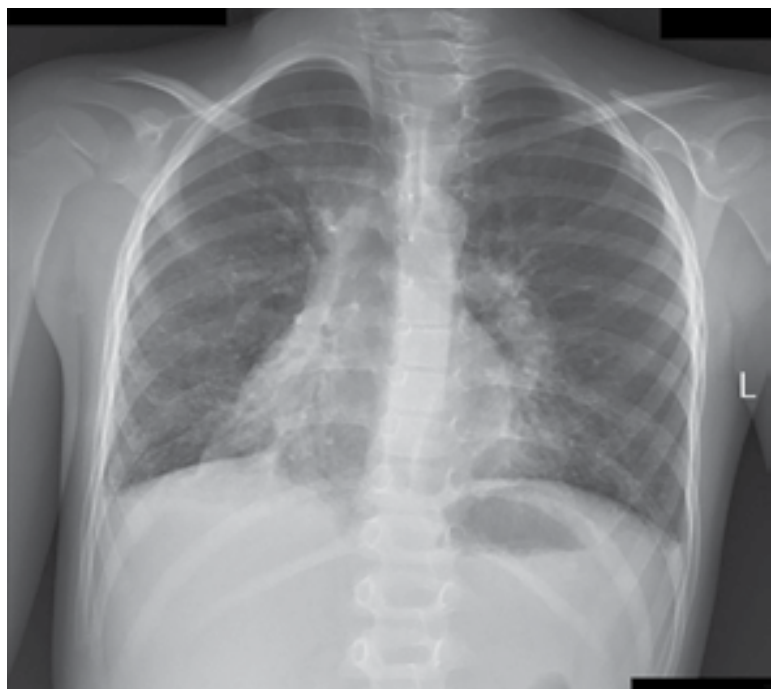

Fig. 1. Chest $x$-ray

to pneumonia took place at 3 and 5 months of age, the latter one accompanied by airway obstruction. The girl was referred to a pulmonology centre, where (inhaled and food) allergy was excluded, for further treatment and extended diagnosis. An ENT examination showed accumulated discharge at the entrance to the larynx and in the glottis. Systemic glucocorticoids (GCS), bronchodilators, clarithromycin and kinesitherapy were used, leading to resolution of obstruction, auscultatory symptoms and overall clinical improvement. The patient was diagnosed with early-onset asthma and put on chronic inhaled GCS therapy. At 20 months of age, the girl was re-admitted for pneumonia. IV antibiotic therapy, systemic and inhaled GCS, and bronchodilators were used in the treatment. Patient's condition improved, but recurrent obstruction and problems with systemic GCS discontinuation were still observed despite the treatment. After 10-day therapy, the girl was discharged with recommendations to continue treatment and to report for allergological and pulmonological consultations.

At the age of four years, the child was re-admitted due to pneumonia. Lung radiography (Fig. 1) showed consolidation of parenchymal atelectatic lesions in the midlower parts of the right lung (probably the lower lobe). Furthermore, the description included diffuse parenchymal densities, with the largest lesions located in the lower pulmonary fields and in the perihilar region. Slight amounts of fluid were present in both pleural cavities. Laboratory tests showed increased acute inflammatory markers: C-reactive protein (CRP) $66 \mathrm{mg} / \mathrm{L}$, white blood cells (WBC) 18.09 thousand/ $\mu \mathrm{L}$. Antibiotic treatment (amoxicillin/clavulanic acid, clarithromycin), bronchodilators, inhaled GCSs and mucolytics were administrated. Transient increase in inflammatory markers (CRP $127 \mathrm{mg} / \mathrm{L}, \mathrm{WBC}$ 24.33 thousand $/ \mu \mathrm{L}$ ) was observed. The treatment led to improvement in overall condition and partial reduction of auscultatory symptoms. 


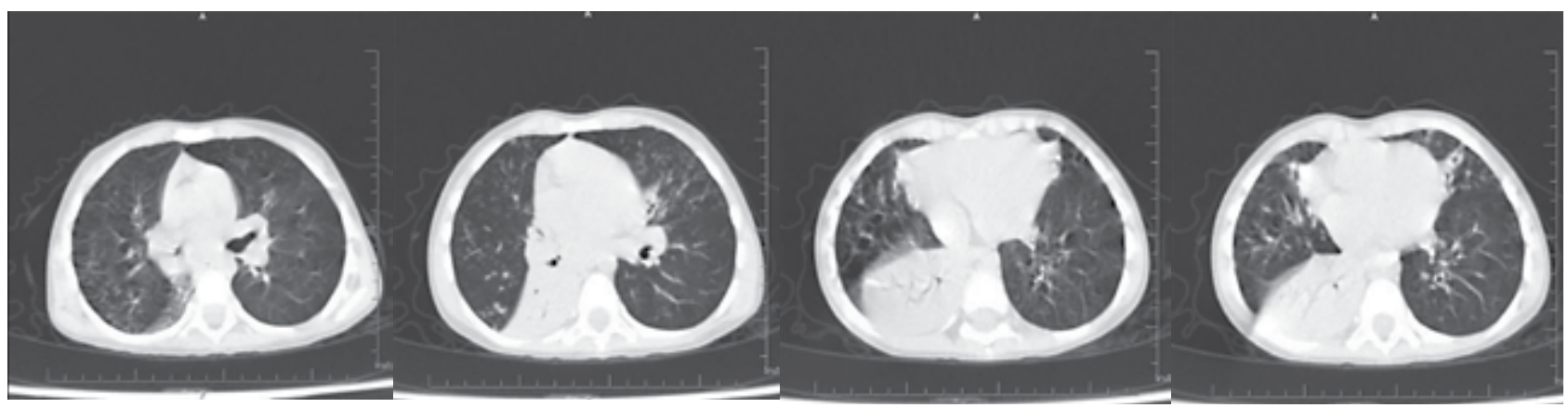

Fig. 2. Lung HRCT. Atelectasis of the entire lower right lobe with aerated bronchial tree (the picture is suggestive of chronic lesions). Other than that, multiple centrilobular nodular densities, merging focally into the areas of peribronchial atelectasis with marked reduction in the volume of lung tissue are present in the lingula and middle lobe as well as the basal part of the lower left lobe; similar, less severe lesions in the lower part of the right segment 2 and upper part of the right segment 3 , with the presence of several slightly larger (5-6 mm) foci of densities. Narrowed middle lobe bronchi, narrower, irregular segmental bronchi of the right lower lobe

Also, the girl's parents reported the presence of chronic wet cough with expectoration of secretions, nasal obstruction and chronic rhinitis from birth.

The girl was admitted to the Department of Pulmonology at the Institute of Tuberculosis and Lung Diseases a month after the last hospitalization. She was in fairly good overall condition at admission. Physical examination revealed a hyposthenic body type, slightly marked signs of dyspnoea, such as tachypnoea, involvement of additional respiratory muscles, retraction at the suprasternal notch, nasal obstruction malocclusion, multiple diffuse crackles, multiple bilateral dry rales, and subscapular bronchial respiratory sound on auscultation; clubbed fingers. Furthermore, there was a delayed speech development the girl used single indistinct words. Remarkable laboratory findings included increased inflammatory markers: CRP $23 \mathrm{mg} / \mathrm{L}, \mathrm{WBC} 16.6$ thousand/L, erythrocyte sedimentation rate (ESR) $44 \mathrm{~mm}$, alpha-1 antitrypsin $2.438 \mathrm{~g} / \mathrm{L}$, complement component C3 $1.411 \mathrm{~g} / \mathrm{L}$. The diagnosis was extended to include sweat test (normal) and upper nasal nitric oxide (nNO) testing (unsuccessful - lack of cooperation). Lung ultrasonography showed extensive atelectasis in the lower right lobe with abolition of bronchial aeration as well as irregular pleura with Z-lines in the basal part of the lungs, and fine consolidation/atelectasis foci in the region of the middle lobe and the lingula. The diagnosis was extended to include high-resolution computed tomography (HRCT) (Fig. 2). Bronchoscopy revealed small amounts of purulent fluid on the tracheal walls; with large amounts of purulent discharge filling the bronchi of both lungs, with right-sided predominance. Samples were collected to investigate the cilia under a light microscope. Moderately numerous conglomerates of ciliary epithelium covered with normal-length cilia were obtained, which showed no movement in most of the fragments (only stiff beat and oscillations around the long axis were occasionally observed). Haemophilus influenzae was present in bronchial culture, with $85 \%$ of neutrophils in cy- with effusion was diagnosed, but hearing assessment was not possible (uncooperative patient). The girl developed fever and increased dyspnoea requiring temporary use of passive oxygen therapy after bronchoscopy. Inflammatory markers increased. The patient was put on antibiotic therapy, mucolytics, and bronchial drainage, which led to significant improvement of her overall condition, normalisation of inflammatory markers and partial resolution of auscultatory symptoms. Follow-up lung ultrasound showed systematic regression of lesions, reduced atelectasis in the entire lower lobe up to the segment 10 in the right lung. Primary ciliary dyskinesia (PCD) was diagnosed based on the overall clinical picture, basic examinations and laboratory testing.

Genetic testing and ciliary evaluation using electron microscopy and immunofluorescence were ordered. No epithelial cilia or microvilli were found in ultrastructural assessment using an electron microscope. No basal bodies were found in the apical epithelial cell layer. The obtained findings and the clinical picture confirmed PCD. Other results were still analysed at the time of publication of the article.

\section{DISCUSSION}

PCD is a rare genetic disease. The symptoms occur as a result of abnormal structure/function of cilia covering the epithelium of the mucous membranes of sinuses, bronchi, reproductive tract, and the central nervous system.

PCD is inherited in an autosomal recessive manner, with a prevalence of about 1:10,000-40,000 live-born children ${ }^{(2)}$. Almost 40 genes are responsible for ciliary defects and, abnormal ciliary movement. A normal cilium is made up of $9(A+B)$ symmetrically arranged peripheral microtubule doublets and 1 centrally located doublet. Inner and outer dynein arms are attached to the peripheral microtubule doublets. The peripheral doublets are connected by nexin links, whereas the so called radial spokes attach them to the central doublet. Normal structure determines proper movement (Fig. 3). 


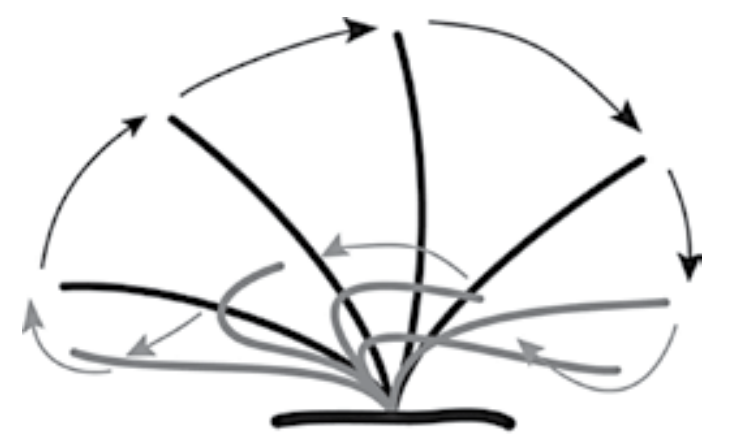

Fig. 3. Normal ciliary structure and ciliary beat pattern ${ }^{(3,4)}$

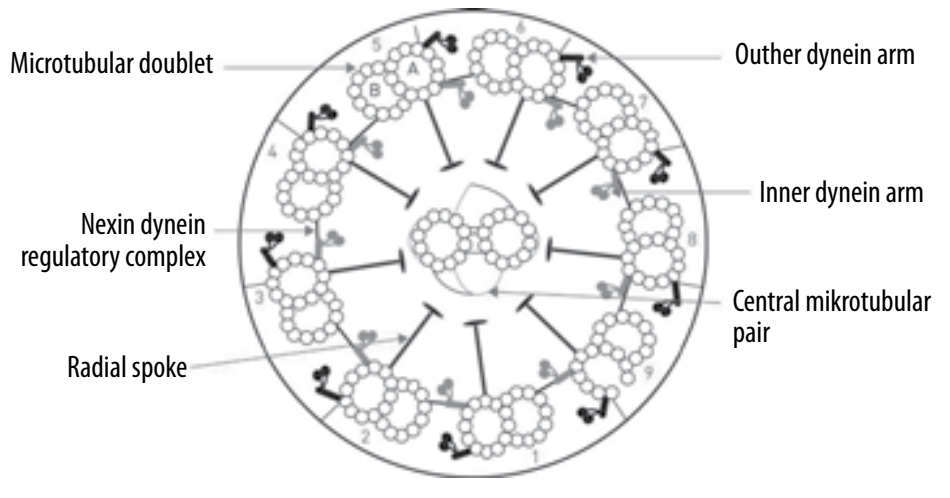

to the general population ${ }^{(7)}$. Impaired ciliary clearance leads to recurrent respiratory infections. Particular attention should be paid to recurrent or chronic otitis media and recurrent bronchitis, which, over time, progress to chronic bronchitis followed by bronchiectasis at a later age. The middle lobe, lingula or lower lobes are a common location. Chronic, productive cough with expectoration of mucopurulent discharge is a typical symptom. These symptoms are accompanied in older children by chronic paranasal sinusitis and, often, hearing impairment. About $50 \%$ of adult men are affected by infertility due to the lack of sperm motility; aspermia is diagnosed in some patients. Abnormal ciliary movement in the fallopian tubes may lead to ectopic pregnancy in women ${ }^{(8)}$.

The diagnosis of PCD requires specialist equipment and is performed in specialist centres. Therefore, PICADAR occur already from the first days of life. Congenital heart defects are more common in patients with PCD compared

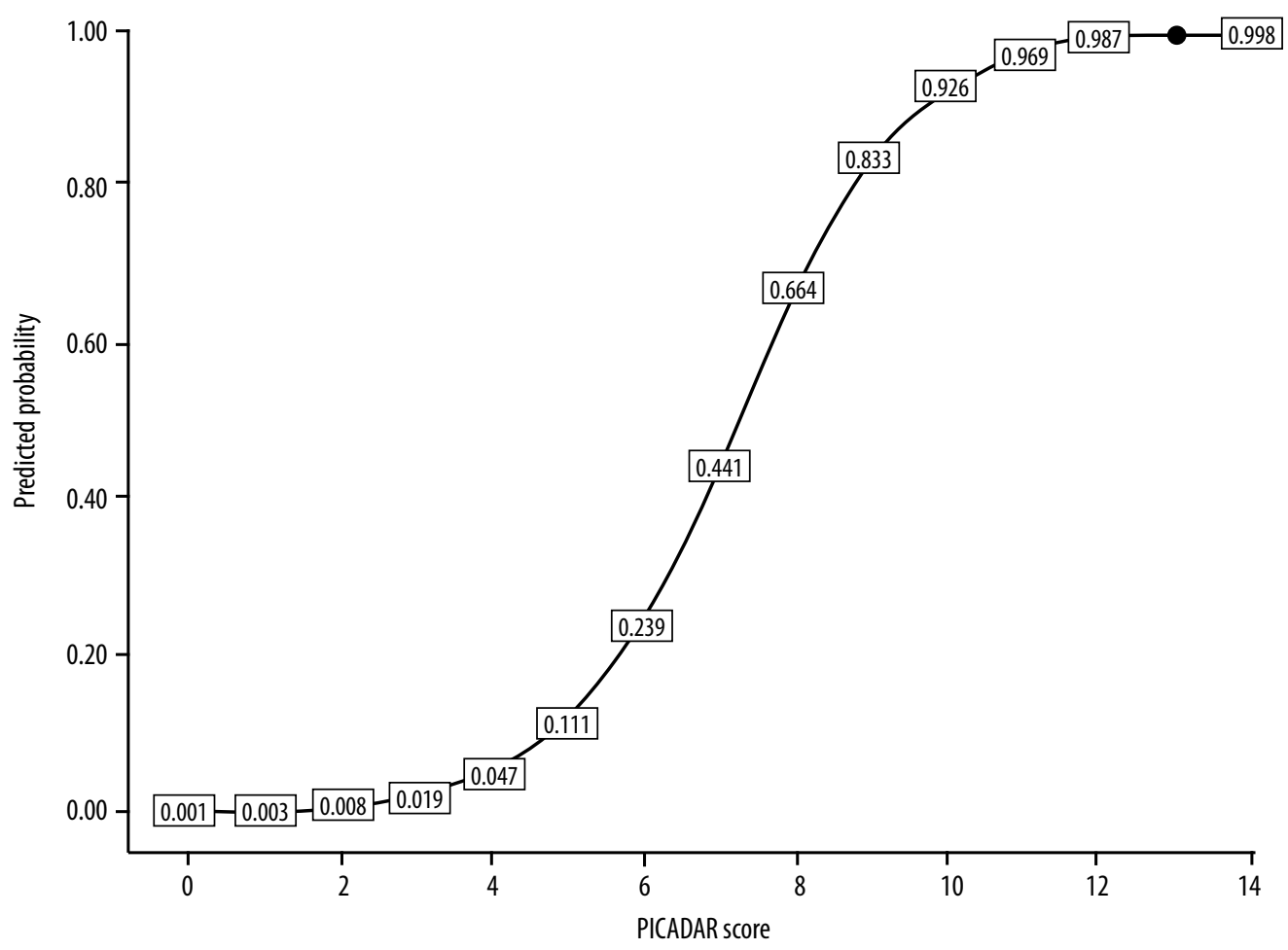

Fig. 4. The probability of $P C D^{(9)}$ 


\begin{tabular}{|c|c|c|}
\hline $\begin{array}{l}\text { Does the patient have a daily productive cough that } \\
\text { started in early childhood? }\end{array}$ & $\begin{array}{c}\text { NO } \\
\text { (the probability of PCD cannot be estimated based on PICADAR) }\end{array}$ & YES \\
\hline 1. Was the patient born preterm or full-term? & Preterm $=0$ & Full-term $=2$ \\
\hline $\begin{array}{l}\text { 2. Did the patient experience chest symptoms in the neonatal } \\
\text { period (e.g. tachypnoea, cough, pneumonia)? }\end{array}$ & $\mathrm{N} 0=0$ & $\mathrm{YES}=2$ \\
\hline $\begin{array}{l}\text { 3. Did the patient require prolonged hospitalisation } \\
\text { or re-admission during the neonatal period? }\end{array}$ & $\mathrm{N} 0=0$ & $\mathrm{YES}=2$ \\
\hline $\begin{array}{l}\text { 4. Does the patient have a situs abnormality (situs inversus } \\
\text { or heterotaxy)? }\end{array}$ & $\mathrm{N} 0=0$ & $\mathrm{YES}=4$ \\
\hline 5. Does the patient have a congenital heart defect? & $\mathrm{N} 0=0$ & $\mathrm{YES}=2$ \\
\hline 6. Does the patient have persistent perennial rhinitis? & $\mathrm{N} 0=0$ & $\mathrm{YES}=1$ \\
\hline $\begin{array}{l}\text { 7. Does the patient experience chronic ear or hearing } \\
\text { symptoms (e.g. chronic otitis media with effusion, hearing } \\
\text { loss, tympanic membrane perforation)? }\end{array}$ & $\mathrm{N} 0=0$ & $\mathrm{YES}=1$ \\
\hline & TOTAL: & \\
\hline
\end{tabular}

Tab. 2. PICADAR questionnaire(9)

(PrImary CiliAry DyskinesiA Rule), which is a predictive score for patients with chronic productive cough resistant to standard treatment was developed. It consists of 7 questions for outpatient diagnosis. The questionnaire is used to assess the likelihood of PCD in a given patient (Tab. 2, Fig. 4). The sensitivity and specificity of the tool are 0.90 and 0.75 for a cut-off score of 5 points ${ }^{(9)}$. Patients with a score $>10$ have a $90 \%$ probability of testing positive for PCD. A score $>5$ indicates a $>11 \%$ chance of $\mathrm{PCD}^{(6)}$. The questionnaire begins with the so-called entry criterion, i.e. a question which requires a positive answer: if such answer is not given, the questionnaire is not continued (Tab. 2).

Our patient had a PICADAR score of 8 , which indicates $>60 \%$ likelihood of PCD.

Nasal nitric oxide (nNO) is another tool used in the diagnosis of PCD. The method is non-invasive, sensitive, and rapid, with immediately available results. However, it is used in adults and children $>5$ years of age due to the need for patient's cooperation. Values below $250 \mathrm{ppb}$ are found in patients with PCD. A value of $105 \mathrm{ppb} / 77 \mathrm{~nL} / \mathrm{min}$ shows $100 \%$ sensitivity and $88 \%$ specificity ${ }^{(10)}$. Low nNO levels may be also reported in cystic fibrosis, chronic sinusitis or nasal polyps as well as during viral infections with rhinitis. Therefore, the measurement should be performed after the recovery period (about 8 weeks after infection) ${ }^{(11)}$. Unfortunately, this tool is not widely available. nNO screening was unsuccessful in our patient due to the lack of cooperation.

High-speed video microscopy analysis (HSVA), which records at 120-500 frames per second with possible assessment of motion at a slow rate (30-60 frames per second fps), is an important element of diagnosis in patients with $\mathrm{PCD}^{(3)}$. Fresh, biopsy samples from under the inferior concha or bronchus are investigated using a light microscope, which allows for the assessment of ciliary type and movement rate. HSVA shows high sensitivity (100\%) and specificity (96\%) in the diagnosis of $\mathrm{PCD}^{(12)}$. Under normal conditions, ciliary movement frequency is $8-15 \mathrm{~Hz}$, with lower values for cilia sampled from more peripheral airways. Normal beat pattern is synchronised (Fig. 3). It is described as a sequence of consecutive beats: a strong beating stroke of an upright cilium followed by a recovery stroke, which is initiated by bending of the proximal axoneme ${ }^{(4)}$. Ciliary beat abnormalities include static cilia, slow, stiff or rotational beating, reduced bending amplitude, hyperkinetic cilia or impaired coordination. HSVA is performed in highly specialised centres. So far, no standards have been developed for this method, and there are inter-centre differences in the results. In the presented case, moderately numerous conglomerates of ciliated epithelium were observed. These conglomerates were covered by cilia of normal length, which showed no movement in most of the evaluated fragments or only occasional abnormal movement (stiff beats, oscillations around the long axis). Normal ciliary ultrastructure may be assessed with transmission electron microscopy (TEM). PCD may be diagnosed based on the identification of typical PCD features, such as absence of outer dynein arms, absence of both inner and outer dynein arms, or absence of inner and outer dynein arms accompanied by abnormal microtubule structure, without the need for further diagnosis ${ }^{(8)}$. Abnormal ciliary ultrastructure is not visualised in $20 \%$ of patients with typical PCD symptoms ${ }^{(8)}$. Biopsy should be performed during recovery, i.e. at least 2 weeks after exacerbations, to exclude secondary causes ${ }^{(11)}$. In the case of doubts arising from patient's exposure to environmental or infectious factors, or technical reasons, in vitro epithelial culture may be performed. Epithelial culture reduces the number of false positive results. It helps evaluate rare cases, such as ciliary agenesis, and limits the need for further biopsies ${ }^{(13)}$.

Immunofluorescence is a less available and less commonly used method. It involves visualizing individual ciliary components using florescent markers. A number of anti-ciliary antibodies are available, including those directed against outer and inner dynein arms, radial spokes and nexin links. Immunofluorescence allows the detection of all ultrastructural abnormalities visible under an electron microscope 


\begin{tabular}{|l|l|l|}
\hline & Asthma & PCD \\
\hline Cough & Dry & Wet \\
\hline Symptoms & Periodical/seasonal & Full year \\
\hline Rhinitis & $\begin{array}{l}\text { Seasonal - watery, responsive to antihistamines and intranasal GCS } \\
\text { Full year - nasal congestion }\end{array}$ & $\begin{array}{l}\text { Full year, unresponsive to antihistamines } \\
\text { and intranasal GCS }\end{array}$ \\
\hline ENT problems & No & Recurrent otitis media with effusion \\
\hline Symptom onset & Individual & Neonatal \\
\hline $\begin{array}{l}\text { Auscultatory } \\
\text { abnormalities }\end{array}$ & $\begin{array}{l}\text { Obstruction, prolonged expiration, wheezing } \\
\text { No auscultatory changes between exacerbations }\end{array}$ & $\begin{array}{l}\text { Polyphonic crackles, rhonchi } \\
\text { Periodical wheezing }\end{array}$ \\
\hline Treatment & Inhaled GCS & Mucolytics, drainage \\
\hline
\end{tabular}

Tab. 3. Differences and similarities between PCD and asthma

and cases where the picture is apparently normal or slightly abnormal. The sensitivity and specificity of immunofluorescence are unknown. The results depend on the quality and combination of antibodies used. False negative results are possible if an abnormal protein is present in the cilium ${ }^{(3)}$. Genetic analysis is another diagnostic method. So far, 39 PCD-associated genes have been identified ${ }^{(5)}$. A combination of 2 mutations is needed for the diagnosis. Unfortunately, known mutations are detected in only about $65 \%$ (50-75\%) of patients. There are ongoing studies to identify further mutations ${ }^{(3)}$.

Differential diagnosis of suspected PCD should include all disease entities characterised by chronic productive cough (Tab. 1) and chronic rhinitis leading to bronchiectasis. It should be emphasised that patients with PCD are at the beginning treated the same way as those with asthma. Obstructive defects in functional tests can be seen with both PCD and asthma. Bronchodilator responsiveness is not exclusive to asthma and does not exclude $\mathrm{PCD}^{(11)}$. Similarities and differences between the symptoms of PCD and asthma are summarised in Tab. 3.

\section{Treatment}

Due to the lack of randomised clinical trials, the recommendations for the treatment of PCD are based on the treatment guidelines for chronic pulmonary diseases, cystic fibrosis (CF) in particular ${ }^{(14)}$. Although the symptoms seen in patients with PCD and CF are similar, their mechanisms differ: PCD - retention of normal secretions, CF retention of excessively thick secretions.

Treatment aims include prevention of bronchiectasis and maintaining good pulmonary function. Evacuation of secretions using appropriate, age-matched physical therapy, respiratory gymnastics and physical exercise, is also one of the key measurements.

Efficacy of mucoactive agents has been described: recombinant human DNAse and hypertonic saline. The benefits of $\mathrm{N}$-acetylcysteine treatment and chronic use of bronchodilators have not been confirmed ${ }^{(14)}$.

Aggressive antibiotic therapy of upper and lower respiratory tract infections should include pathogens that are most common in PCD: H. influenzae, S. aureus and S. pneumoniae.
Due to the large amount of secretion in the respiratory tract, $P$. aeruginosa should be also considered.

ENT care and treatment is also necessary in patients with impaired sinus drainage, chronic paranasal sinusitis and hearing impairment.

Avoiding active and passive smoking, elimination of exposure to environmental pollution and minimising exposure to pathogens play a key role in all patients. Vaccinations are also important ${ }^{(14)}$.

\section{CONCLUSIONS}

The diagnosis of PCD is delayed or missed in the diagnostic process of chronic and recurrent respiratory infections ${ }^{(15)}$. The median age at diagnosis is 5.3 years in Europe. This age is lower in patients with situs inversus, i.e. 3.5 years vs. 5.8 years $^{(6)}$. Early diagnosis is aimed at delaying pulmonary complications, such as bronchiectasis, reducing lung dysfunction and hearing impairment, as well as optimal treatment of rhinitis and sinusitis. Patients with PCD require multidisciplinary care with cooperation of a pulmonologist, ENT specialist and physiotherapist. Systematic assessment of respiratory function, bacterial sputum culture, lung imaging and audiogramme are recommended for these patients.

\section{Conflict of interest}

The authors do not report any financial or personal connections with other persons or organizations, which might negatively affect the contents of this publication and/or claim authorship rights to this publication.

\section{References}

1. Lange J: Diagnostyka chorób układu oddechowego. Objawy. In: Kulus M, Krenke K (eds.): Pulmonologia dziecięca. PZWL, Warszawa 2018: 31-39.

2. Damseh N, Quercia N, Rumman N et al.: Primary ciliary dyskinesia: mechanisms and management. Appl Clin Genet 2017; 10: $67-74$.

3. Lucas JS, Barbato A, Collins SA et al.: European Respiratory Society guidelines for the diagnosis of primary ciliary dyskinesia. Eur Respir J 2017; 49: 1601090.

4. Raidt J, Wallmeier J, Hjeij R et al.: Ciliary beat pattern and frequency in genetic variants of primary ciliary dyskinesia. Eur Respir J 2014; 44: 1579-1588. 
5. Shapiro AJ, Davis SD, Polineni D et al.: Diagnosis of primary ciliary dyskinesia. An official American Thoracic Society clinical practice guideline. Am J Respir Crit Care Med 2018; 197: e24-e39.

6. Mirra V, Werner C, Santamaria F: Primary ciliary dyskinesia: an update on clinical aspects, genetics, diagnosis, and future treatment strategies. Front Pediatr 2017; 5: 135.

7. Mazurek H: Rozstrzenie oskrzeli. In: Mazurek H (ed.): Zakażenia układu oddechowego u dzieci. Medical Tribune Polska, Warszawa 2014: 239-261.

8. Grzela K: Zespół dyskinetycznych rzęsek. In: Kulus M, Krenke K (eds.): Pulmonologia dziecięca. PZWL, Warszawa 2018: 328-332.

9. Behan L, Dimitrov BD, Kuehni CE et al.: PICADAR: a diagnostic predictive tool for primary ciliary dyskinesia. Eur Respir J 2016; 47: 1103-1112.

10. Corbelli R, Bringolf-Isler B, Amacher A et al.: Nasal nitric oxide measurements to screen children for primary ciliary dyskinesia. Chest 2004; 126: 1054-1059.
11. Shapiro AJ, Zariwala MA, Ferkol T et al.; Genetic Disorders of Mucociliary Clearance Consortium: Diagnosis, monitoring, and treatment of primary ciliary dyskinesia: PCD foundation consensus recommendations based on state of the art review. Pediatr Pulmonol 2016; 51: 115-132.

12. Rubbo B, Shoemark A, Jackson CL et al.; National PCD Service, UK: Accuracy of high-speed video analysis to diagnose primary ciliary dyskinesia. Chest 2019; 155: 1008-1017.

13. Hirst RA, Rutman A, Williams $\mathrm{G}$ et al.: Ciliated air-liquid cultures as an aid to diagnostic testing of primary ciliary dyskinesia. Chest 2010; 138: 1441-1447.

14. Snijders D, Calgaro S, Pifferi M et al.: Primary ciliary dyskinesia. In: Eber E, Midulla F (eds.): ERS Handbook. Pediatric Respiratory Medicine. European Respiratory Society, 2013: 551-558.

15. Behan L, Dunn Galvin A, Rubbo B et al.: Diagnosing primary ciliary dyskinesia: an international patient perspective. Eur Respir J 2016; 48: 1096-1107. 